\title{
Do the politics or business background of health care philanthrophists matter?
}

Cite as: CMAJ 2019 August 19;191:E924-5. doi: 10.1503/cmaj.109-5781

Posted on cmajnews.com on July 31, 2019.

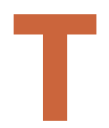
he Hospital for Sick Children (SickKids) in Toronto recently received a \$100-million donation from the Peter Gilgan Foundation, the largest gift in its history. Together with previous gifts to health organizations, the donation made Peter Gilgan the largest health care benefactor in Canada.

The gift will contribute to the $\$ 1.3-$ billion SickKids VS Limits campaign, which involves redeveloping its campus and building the Peter Gilgan Family Patient Care Tower.

Amid excitement about the donation, however, some social media users noted that Gilgan's company, Mattamy Homes, was also the top donor to Ontario Proud, a right-wing political advocacy group credited with helping Doug Ford's Progressive Conservative Party win the Ontario election.

Among them was Sarah Colero, a 23-year-old Toronto woman who received care at SickKids as a child. Colero said she was "extremely happy" when she heard about the donation but was taken aback after learning of Gilgan's connection to Ontario Proud. Colero said she knows the donation will benefit SickKids but feels the ties to the controversial advocacy group reflect poorly on the hospital.

In a statement in December 2018, Mattamy Homes said it made a one-time contribution to Ontario Proud to advance the housing agenda during the provincial election. The release said Mattamy Homes does not share Ontario Proud's views on other issues and will refrain from making contributions to political advocacy groups in the future.

According to Benjamin Soskis, a research associate at the Center on Nonprofits and Philanthropy at the Urban Institute in Washington, DC, there has

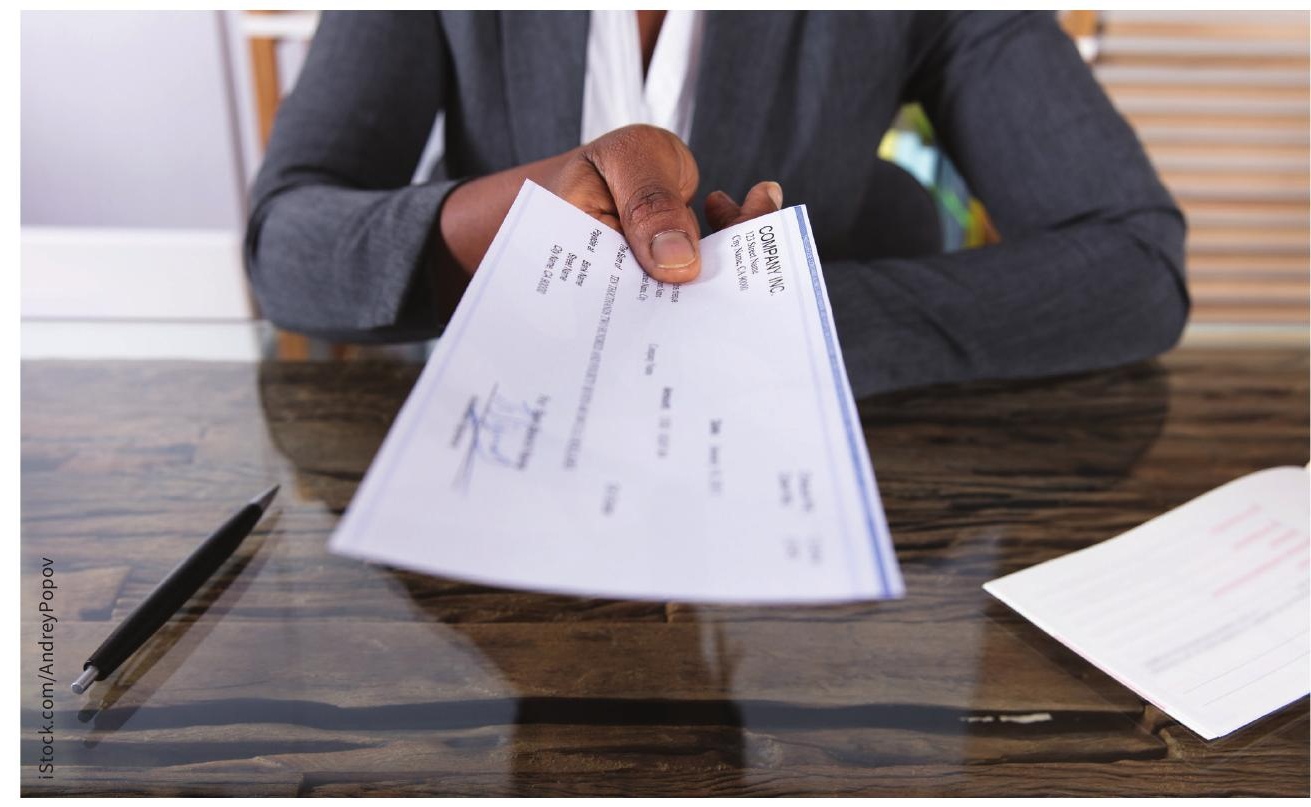

Health care institutions tend to accept gifts from controversial donors if there is no direct conflict with the institution's objectives.

long been a tendency to ignore the controversies or politics of philanthropic donors. "For a century, and even longer, there's been a general sense that you don't really look the gift horse in the mouth," said Soskis.

Recently, however, several high-profile institutions have turned away money from donors because of their political or business backgrounds. This spring, institutions including the Guggenheim Museum in New York and the Tate galleries in London announced they would no longer accept donations from the Sackler family, which amassed much of its fortune from opioids. More recently, the University of Alabama returned a \$21.5-million gift from Hugh Culverhouse Jr. after he urged students and businesses to boycott the university and the state because of its new anti-abortion law.
In general, donations to medical research tend to attract less controversy, said Soskis. In 2007, David H. Koch, an American billionaire and major funder of conservative causes, donated $\$ 100$ million to help build a cancer research centre at the Massachusetts Institute of Technology. The director of the research centre, Tyler Jacks, told The New York Times that although the campus was aware of Koch's political activities, there was an appreciation that "cancer is an apolitical problem."

David Allyn, vice president at GrahamPelton, a fundraising and management consulting firm for nonprofits, argues that rejecting money from controversial donors is often a short-sighted move. He suggests that institutions make decisions consistent with their mission statements and have strong gift-acceptance policies to consult when issues arise. 
For example, the SickKids Foundation's gift policy allows donations from all sources except those that might be associated with criminal behaviour, according to its CEO, Ted Garrard.

"A donor or prospective donor's political leanings or affiliations have no bearing on their gifts to SickKids Foundation. Furthermore, they have no influence on how the gifts are used; nor shall this be perceived as an endorsement of any kind," Garrard said of the donation made by Gilgan, whom he described as "a long-time, committed sup- porter of SickKids [who] cares deeply about children's health."

Allyn thinks society benefits from a nonprofit sector that's as free from political polarization as possible, which means not holding leaders to a standard of moral perfection. "It won't serve anyone as well if well-meaning, idealistic actions lead to the shuttering of worthy institutions," he said.

Beth Breeze, director of the Centre for Philanthropy at the University of Kent, recently wrote an opinion piece in The
Guardian explaining that organizations often make pragmatic decisions about the costs and benefits of accepting cash from controversial donors. Ethics should be considered, however, given that charities must operate with high levels of integrity.

Overall, the most common view Breeze has encountered is "a willingness to set aside personal judgments of any given donor where there is no direct conflict with the charity's objectives."

Caroline Mercer, Toronto, Ont. 